\title{
Health risk assessment of China's main air pollutants
}

\author{
Jian Sun ${ }^{1 *}$ and Tiancai Zhou ${ }^{1,2}$
}

\begin{abstract}
Background: With the rapid development of China's economy, air pollution has attracted public concern because of its harmful effects on health.

Methods: The source apportioning of air pollution, the spatial distribution characteristics, and the relationship between atmospheric contamination, and the risk of exposure were explored. The in situ daily concentrations of the principal air pollutants $\left(\mathrm{PM}_{2.5}, \mathrm{PM}_{10}, \mathrm{SO}_{2}, \mathrm{NO}_{2}, \mathrm{CO}\right.$ and $\left.\mathrm{O}_{3}\right)$ were obtained from 188 main cities with many continuous air-monitoring stations across China (2014 and 2015).

Results: The results indicate positive correlations between $\mathrm{PM}_{2.5}$ and $\mathrm{SO}_{2}\left(R^{2}=0.395 / 0.404, P<0.0001\right)$, $\mathrm{CO}\left(R^{2}=0.187 / 0.365, P<0.0001\right)$, and $\mathrm{NO}_{2}\left(R^{2}=0.447 / 0.533, P<0.0001\right)$, but weak correlations with $\mathrm{O}_{3}(P>0.05)$ for both 2014 and 2015. Additionally, a significant relationship between $\mathrm{SO}_{2}, \mathrm{NO}_{2}$, and $\mathrm{CO}$ was discovered using regression analysis $(P<0.0001)$, indicating that the origin of air pollutants is likely to be vehicle exhaust, coal consumption, and biomass open-burning. For the spatial pattern of air pollutants, we found that the highest concentration of $\mathrm{SO}_{2}, \mathrm{NO}_{2}$, and CO were mainly distributed in north China (Beijing-Tianjin-Hebei regions), Shandong, Shanxi and Henan provinces, part of Xinjiang and central Inner Mongolia (2014 and 2015).

Conclusions: The highest concentration and risk of $\mathrm{PM}_{2.5}$ was observed in the Beijing-Tianjin-Hebei economic belts, and Shandong, Henan, Shanxi, Hubei and Anhui provinces. Nevertheless, the highest concentration of $\mathrm{O}_{3}$ was irregularly distributed in most areas of China. A high-risk distribution of $\mathrm{PM}_{10}, \mathrm{SO}_{2}$ and $\mathrm{NO}_{2}$ was also observed in these regions, with the high risk of $\mathrm{PM}_{10}$ and $\mathrm{NO}_{2}$ observed in the Hebei and Shandong province, and high-risk of $\mathrm{PM}_{10}$ in Urumchi. The high-risk of $\mathrm{NO}_{2}$ distributed in Beijing-Yangtze River Delta region-Pearl River Delta region-central. Although atmospheric contamination slightly improved in 2015 compared to 2014, humanity faces the challenge of reducing the environmental and public health effects of air pollution by altering the present mode of growth to achieve sustainable social and economic development.
\end{abstract}

Keywords: Air pollutants, Haze, Spatial patterns, Health risk, China

\section{Background}

Haze is principally formed by an increase in particle size in the atmospheric medium, which affects atmospheric absorption, emission, and scattering of light. $\mathrm{PM}_{2.5}$ : fine inhalable particles, with diameters that are generally 2.5 micrometers and smaller, and originates from construction sites, unpaved roads, fields, smokestacks or fires, including congregated aerosols (e.g. sulfur dioxide, nitrogen dioxide, carbon monoxide, and so on), black carbon

\footnotetext{
* Correspondence: sunjian@igsnrr.ac.cn

${ }^{1}$ Institute of Geographic Sciences and Natural Resources Research, Chinese Academy of Sciences, 11A, Datun Road, Chaoyang District, Beijing 100101, China

Full list of author information is available at the end of the article
}

(the incomplete combustion of carbonaceous combustibles) [1], dust, sea salt [2], heavy metals, and polycyclic aromatic hydrocarbon [3]. Haze incidents are a relatively new threat to human health [4], air quality [5], global climate change [6], ecological suitability for human settlement, and regional sustainable development.

Recently, haze has become a principal environmental issue in China. Consequently, the causes of particulate pollution have been discussed widely: e.g., secondary aerosol [5], aerosol optical properties [7], and aerosol chemical components [8]. And the formation and evolution mechanism of haze has been similarly explored [9]: e.g., long-lasting haze occurrences in Nanjing [10], a 
winter regional haze in the North China Plain [11], and the heavy haze pollution episode over central and eastern China [12]. In addition, we know that understanding the origin of fine particulate matter is essential to finding appropriate strategies to combat haze and the harm it causes. Thus, the source apportioning of fine particulate during the haze events in Shanghai [13], Harbin [14], and Fuzhou [15] was implemented, and the characteristics of atmospheric carbonyls were documented [16] in Beijing.

We have known for some time that haze boosts air pollution, causing significant harm to human health [17]. Previous studies have reported extensively on cardiovascular disease, lung disease, exposure time, mortality, and the mechanisms of biochemistry for haze. Short-term exposure was investigated in metropolitan areas [18], and the effects of dust-haze on mortality were explored [19]. In fact, the relationship between haze and respiratory diseases in Brunei Darussalam were analyzed, and it was found that $\mathrm{PM}_{10}$ and $\mathrm{CO}$ levels have a significant bearing on the incidence of respiratory diseases [20]. In China, Sun et al. [4] explored the relationship between economic development and air pollution, and they found that the variation explained by both total $\mathrm{SO}_{2}$ emissions and total smoke and dust emissions were 33 and $24 \%$ of pertussis (whooping cough), respectively.

However, source apportioning of fine particulate requires considerable investment in time and money. Thus, in this study, we attempt to analyze source apportioning using data mining. Because the risk of exposure to haze across China has been insufficiently discussed, the object of the present study is to address the relationship between atmospheric contamination and human health in China. Specifically, we seek to accomplish the following: (1) to analyze the spatial-temporal distribution of atmospheric contamination over China; (2) to explore the source apportioning of fine particulate in China; and (3) to analyze the relationship between atmospheric contamination and the risk of human exposure in China.

\section{Methods}

\section{Data collection}

All air measurements $\left(\mathrm{SO}_{2}, \mathrm{NO}_{2}, \mathrm{CO}, \mathrm{O}_{3}, \mathrm{PM}_{10}\right.$, and $\mathrm{PM}_{2.5}$ ) were obtained from 188 main cities with continuous air-monitoring stations (Fig. 1), the stations were set up accord with the standard "Technical regulation for selection of ambient air quality monitoring stations $(\mathrm{HJ}$ 664-2013)", and were obtained from the Ministry of Environmental Protection of the People's Republic of China (http://datacenter.mep.gov.cn/). The disease data of pertussis was collected from China Statistical Yearbook (www.stats.gov.cn, 2004-2015) and China Statistical Yearbook of Health and Family Planning (www.moh. gov.cn, 2004-2015). In addition, the atmospheric contamination was compiled annual means to analyze the spatial- temporal distribution of atmospheric contamination over China, and monthly in every city to analyze the relationships among air pollutions for 2014 and 2015.

\section{Method of health risk assessment}

This study used the risk assessment method of the U.S. Environmental Protection Agency (EPA) [21], which focused on the health risk assessment through inhalation pathway for three kinds of people (adult males, adult females, and children), thus, avoided the effects of population density. The assessment study focuses on the risk of exposure to air pollutants $\left(\mathrm{PM}_{10}, \mathrm{SO}_{2}\right.$, and $\left.\mathrm{NO}_{2}\right)$ in China; $R_{i}$ was the individual health risk for exposure pollution, calculated as Eq. 1 [22]:

$$
R_{i}=A D D_{o p t} \times 10^{-6} /\left(R f d_{i j} \times 70\right)
$$

$A D D_{\text {opt }}$ was the average daily dose, calculated as Eq. 2 [23]:

$$
A D D_{\text {opt }}=(C A \times I R \times E D) /(B W \times A T)
$$

where $\mathrm{CA}$ was the concentration $\left(\mathrm{mg} \mathrm{m}^{-3}\right)$ of air pollutants, the average values of inhalation rate (IR), ED (exposure duration in days) and AT (averaging exposure time in days) were showed in Table 1 [22], and the average weight $(\mathrm{BW})$ was obtained from national physical fitness test communiqués (http://www.gov.cn/test). The $\mathrm{Rfd}_{\mathrm{ij}}$ (reference dose) values for $\mathrm{PM}_{10}, \mathrm{SO}_{2}$, and $\mathrm{NO}_{2}$ referred to the U.S EPA (https://www3.epa.gov/).

Based on the IDW (inverse distance weighted) interpolation method to model the spatial distribution of health risk in China, then, calculated the $\operatorname{Rfd}_{\mathrm{ij}}$ values and reclassified by the national air quality standard to get the expose risk level of air pollutants.

\section{Tools of analysis}

In the present study, the ArcGIS 10.2 (ESRI, Inc., Redlands, CA, USA) was used to draw spatial graphs, and SigmaPlot for Windows 10.0 (Systat Software, Inc., Chicago, IL, USA) was used to conduct correlation and regression analysis. Correlations between different variables were determined using two-tailed Pearson's Correlation at 0.05 levels.

\section{Results}

\section{The size of main air pollutants}

As shown in Fig. 2, the frequency distribution of air pollutant $\left(\mathrm{PM}_{2.5}, \mathrm{SO}_{2}, \mathrm{CO}, \mathrm{NO}_{2}\right.$, and $\left.\mathrm{O}_{3}\right)$ concentrations in 2014 and 2015 was observed. The values of the $\mathrm{PM}_{2.5}$, $\mathrm{SO}_{2}, \mathrm{CO}, \mathrm{NO}_{2}$ and $\mathrm{O}_{3}$ range from $18.58 \mu \mathrm{g} \mathrm{m}^{-3}$ to $130.46 \mu \mathrm{g} \mathrm{m}^{-3}$, from $2.17 \mu \mathrm{g} \mathrm{m}^{-3}$ to $117.82 \mu \mathrm{g} \mathrm{m}^{-3}$, from $0.47 \mu \mathrm{g} \mathrm{m}^{-3}$ to $2.42 \mathrm{mg} \mathrm{m}^{-3}$, from $12.56 \mathrm{\mu g} \mathrm{m}^{-3}$ to $66.09 \mu \mathrm{g} \mathrm{m}^{-3}$, from $48.78 \mu \mathrm{g} \mathrm{m}^{-3}$ to $198.61 \mathrm{\mu g} \mathrm{m}^{-3}$, with median values of $61.44 \mu \mathrm{g} \mathrm{m}^{-3}, 30.11 \mu \mathrm{g} \mathrm{m}^{-3}, 1.12 \mu \mathrm{g} \mathrm{m}^{-3}$, 


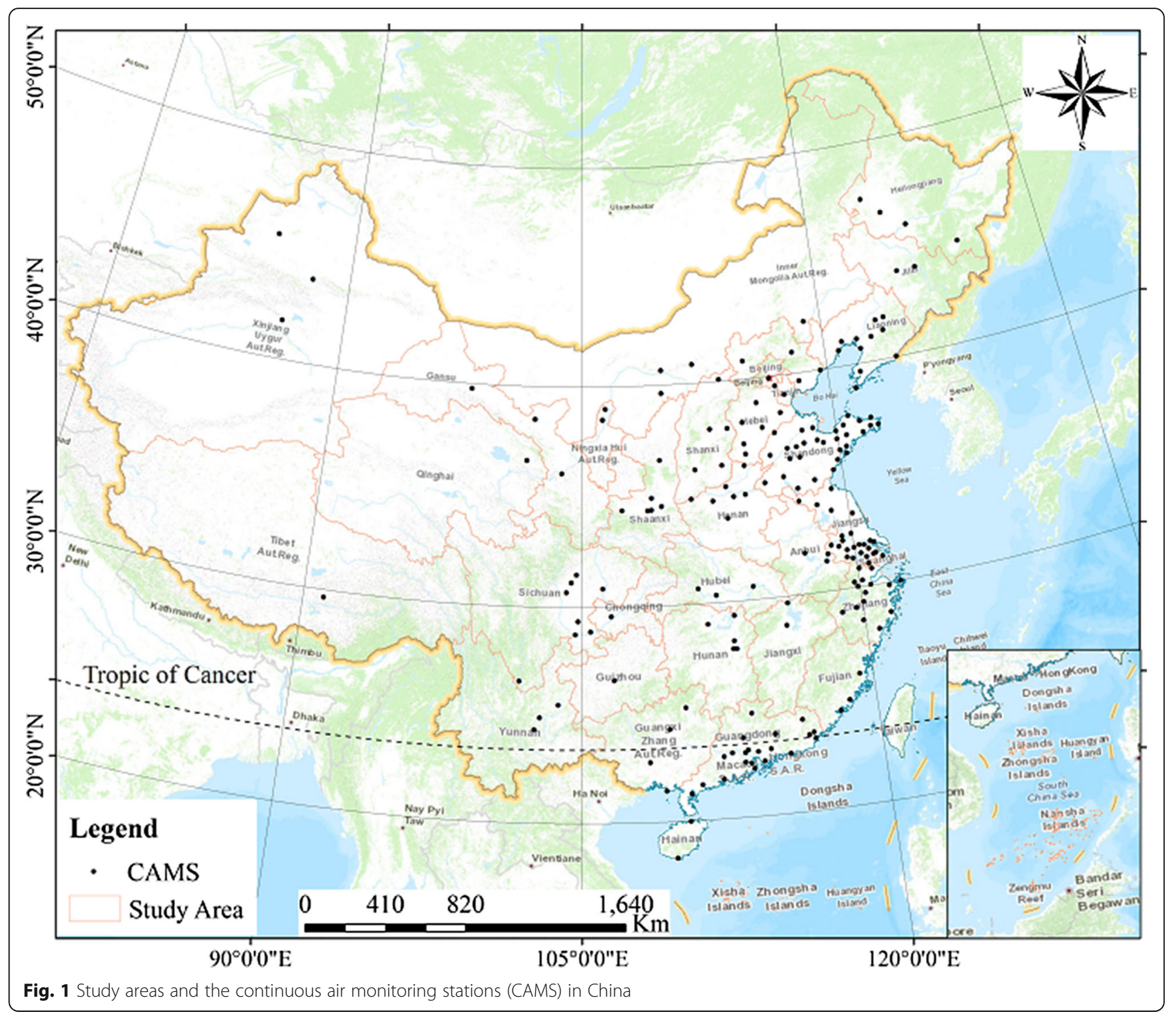

$36.05 \mu \mathrm{g} \mathrm{m}{ }^{-3}, 103.97 \mu \mathrm{g} \mathrm{m} \mathrm{m}^{-3}$, respectively. The high occurrence frequency of the $\mathrm{PM}_{2.5}, \mathrm{SO}_{2}, \mathrm{CO}, \mathrm{NO}_{2}$, and $\mathrm{O}_{3}$ was around $40-75 \mu \mathrm{g} \mathrm{m}^{-3}$, around $15-40 \mu \mathrm{g} \mathrm{m}^{-3}$, around $0.75-1.3 \mathrm{mg} \mathrm{m}^{-3}$, around $25-50 \mu \mathrm{g} \mathrm{m}^{-3}$, and around 75-130 $\mathrm{\mu g} \mathrm{m}^{-3}$ (upper panel). In 2015, there was not only a similar shift in the trend of air pollutants $\left(\mathrm{PM}_{2.5}, \mathrm{SO}_{2}\right.$, $\mathrm{CO}, \mathrm{NO}_{2}$, and $\mathrm{O}_{3}$ ) observed but also the median concentration of air pollutants reduced and centered generally in $52.84 \mu \mathrm{g} \mathrm{m}^{-3}, 23.52 \mu \mathrm{g} \mathrm{m}^{-3}, 1.02 \mathrm{mg} \mathrm{m}^{-3}, 34.18 \mu \mathrm{g} \mathrm{m}^{-3}$,
$102.67 \mu \mathrm{g} \mathrm{m}^{-3}$, respectively. As an example, the values of the $\mathrm{PM}_{2.5}, \mathrm{SO}_{2}, \mathrm{CO}, \mathrm{NO}_{2}$ and $\mathrm{O}_{3}$ range from 17.05 to $106.32 \mu \mathrm{g} \mathrm{m}^{-3}$, from 2.89 to $82.05 \mu \mathrm{g} \mathrm{m}^{-3}$, from 0.44 to $2.36 \mathrm{mg} \mathrm{m}^{-3}$, from 12.84 to $61.24 \mu \mathrm{g} \mathrm{m}^{-3}$, from 58.56 to $136.38 \mu \mathrm{g} \mathrm{m}^{-3}$. In addition, the high occurrence frequency of the $\mathrm{PM}_{2.5}, \mathrm{SO}_{2}, \mathrm{CO}, \mathrm{NO}_{2}$ and $\mathrm{O}_{3}$ narrowed and became more centralized at the range of $25-55 \mu \mathrm{g} \mathrm{m}^{-3}$, around 10 $30 \mu \mathrm{g} \mathrm{m}^{-3}$, around $0.75-1.25 \mathrm{mg} \mathrm{m}^{-3}$, around $25-50 \mu \mathrm{g} \mathrm{m}^{-3}$, and around $90-125 \mu \mathrm{g} \mathrm{m}^{-3}$ (below panel), respectively.

Table 1 Parameters for health risk assessment through inhalation pathway

\begin{tabular}{lcllllll}
\hline Crowds & $\mathrm{IR}\left(\mathrm{m}^{3} / \mathrm{d}\right)$ & $\mathrm{BW}(\mathrm{kg})$ & $\mathrm{ED}(\mathrm{d})$ & $\mathrm{AT}(\mathrm{d})$ & $\mathrm{CA}-\mathrm{PM}_{10}\left(\mathrm{mg} \mathrm{m}^{-3}\right)$ & ${\mathrm{CA}-\mathrm{SO}_{2}\left(\mathrm{mg} \mathrm{m}^{-3}\right)}$ & ${\mathrm{CA}-\mathrm{NO}_{2}\left(\mathrm{mg} \mathrm{m}^{-3}\right)}$ \\
\hline Adult male & 15.2 & 60 & $30 \times 365$ & $30 \times 365$ & 0.15 (National third standard) & 0.06 (National second standard) & 0.04 (National first standard) \\
Adult female & 11.3 & 57 & $30 \times 365$ & $30 \times 365$ & & & \\
Children & 8.7 & 44 & $18 \times 365$ & $18 \times 365$ & & & \\
\hline
\end{tabular}



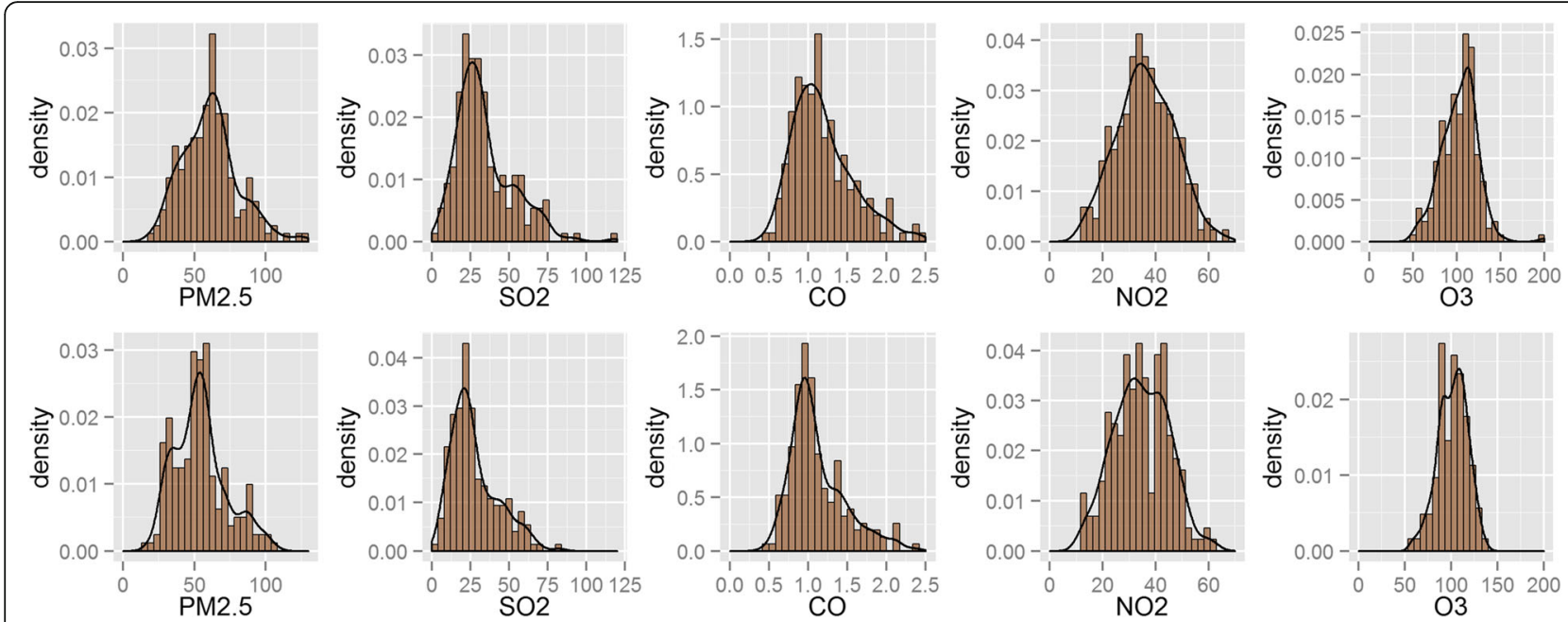

Fig. 2 The frequency distribution of the principal air pollutants. The upper and blow panels represent the documents were collected in 2014 and 2015

\section{Relationships among principal air pollutants over China} from 2014 to 2015

We postulated that the entire concentration of $\mathrm{PM}_{2.5}$ depends on air pollutants $\left(\mathrm{SO}_{2}, \mathrm{CO}, \mathrm{NO}_{2}\right.$, and $\left.\mathrm{O}_{3}\right)$, and, per regression analysis, there are close positive correlations between $\mathrm{PM}_{2.5}$ and $\mathrm{SO}_{2}, \mathrm{CO}, \mathrm{NO}_{2}$ in 2014. In Fig. 3 the appropriate functions of $\mathrm{SO}_{2}, \mathrm{CO}$ and $\mathrm{NO}_{2}$ with $\mathrm{PM}_{2.5}$ are $Y=0.579 X-1.485 \quad\left(R^{2}=0.395, \quad P<0.0001\right)$ (Fig. 3a), $\quad Y=0.008 X+0.678 \quad\left(R^{2}=0.187, \quad P<0.0001\right)$ (Fig. 3b), and $Y=0.357 X+14.32\left(R^{2}=0.447, P<0.0001\right)$
(Fig. 3c), respectively. However, there was a weak correlation trend between $\mathrm{PM}_{2.5}$ and the concentration of $\mathrm{O}_{3}$ $(P>0.05)$ (Fig. 3d). Compared to other air pollutants, $\mathrm{NO}_{2}$ had the greatest influence on $\mathrm{PM}_{2.5}$. Thus, the contribution rate of $\mathrm{SO}_{2}$ and $\mathrm{NO}_{2}$ is as high as $44.7 \%$ for $\mathrm{PM}_{2.5}$.

As illustrated in Fig. 4, the concentration of $\mathrm{PM}_{2.5}$ had been increasing with the rise of $\mathrm{SO}_{2}, \mathrm{CO}, \mathrm{NO}_{2}$, and there are significant relationships between them. High correlation coefficients were noted between $\mathrm{SO}_{2}\left(R^{2}=0.404\right.$,
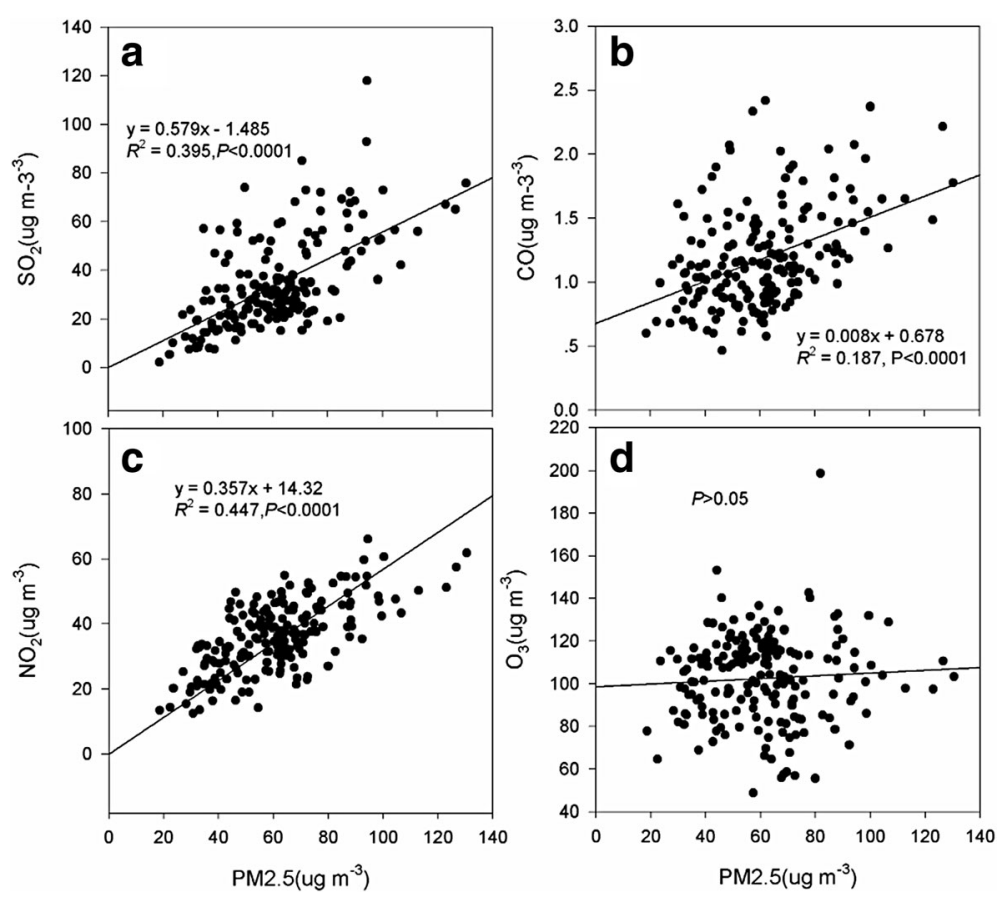

Fig. 3 The $\mathrm{PM}_{2.5}$ was explained by the principal air pollutants over China (2014), and graph a, b, $\mathbf{c}$, and $\mathbf{d}$ represent $\mathrm{SO}_{2}, \mathrm{CO}, \mathrm{NO}_{2}, \mathrm{O}_{3}$, respectively 

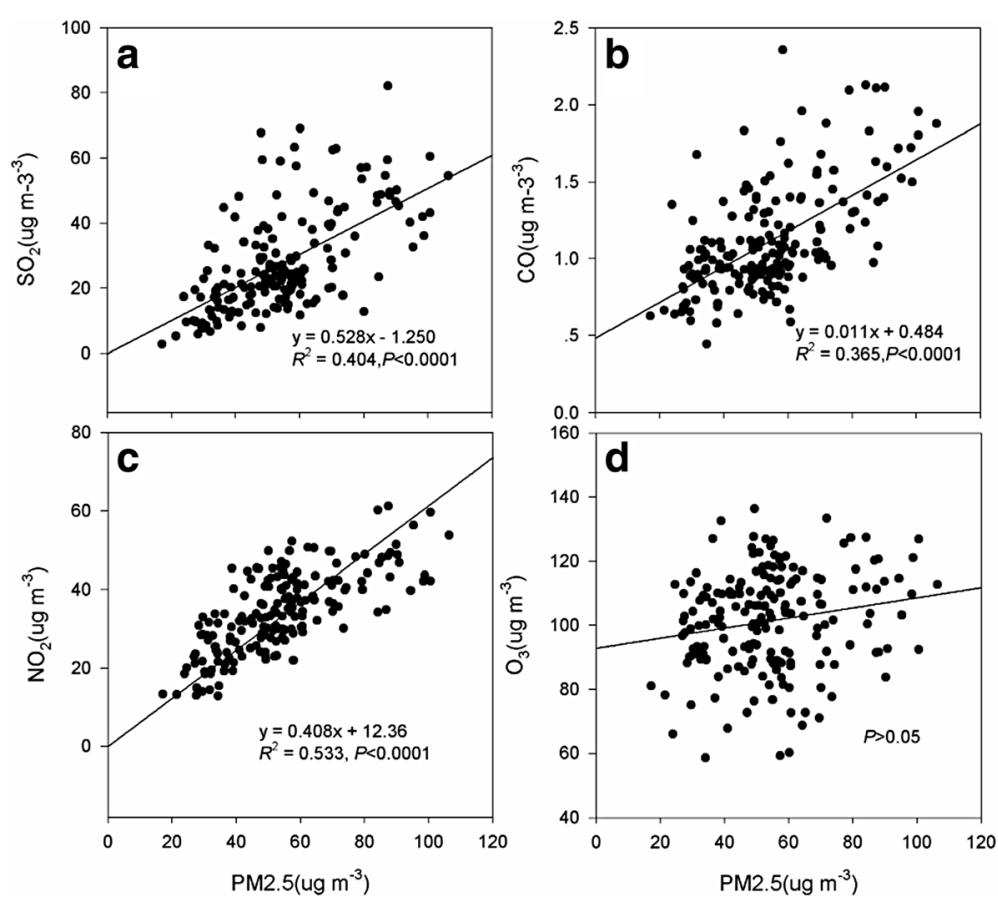

Fig. 4 The $\mathrm{PM}_{2.5}$ was explained by the principal air pollutants over China (2015), and graph a, b, $\mathbf{c}$, and $\mathbf{d}$ represent $\mathrm{SO}_{2}, \mathrm{CO}, \mathrm{NO}_{2}, \mathrm{O}_{3}$, respectively

$P<0.0001$, Fig. 4a), CO $\left(R^{2}=0.365, P<0.0001\right.$, Fig. 4b), $\mathrm{NO}_{2}\left(R^{2}=0.533, P<0.0001\right.$, Fig. 4c $)$ and $\mathrm{PM}_{2.5}$, which illustrates that the $\mathrm{PM}_{2.5}$ are significantly associated with $\mathrm{SO}_{2}$, and $\mathrm{NO}_{2}$, with $\mathrm{CO}$ following, but there were no observable relationships between $\mathrm{PM}_{2.5}$ and $\mathrm{O}_{3}$ (Fig. 4d).

Based on regression analysis, we found close relationships among $\mathrm{SO}_{2}, \mathrm{CO}$ and $\mathrm{NO}_{2}$ in 2014 and 2015. The appropriate functions were $Y=0.011 X+0.805\left(R^{2}=0.289\right.$, $P<0.0001) \quad$ (Fig. 5a), $Y=0.320 X+25.28 \quad\left(R^{2}=0.306\right.$, $P<0.0001)$ (Fig. 5c), and $Y=10.41 X+23.84\left(R^{2}=0.139\right.$, $P<0.0001$ ) (Fig. 5e) in 2014. Similar positive correlations were also observed in 2015 with $R^{2}=0.386(P<0.0001$, Fig. 5b), $R^{2}=0.230(P<0.0001$, Fig. $5 \mathrm{~d})$, and $R^{2}=0.271$ $(P<0.0001$, Fig. 5f), respectively.

\section{Spatial patterns of air pollutants in China from 2014 to 2015}

According to the spatial distribution of air pollutants in China in 2014 (Fig. 6), we discovered that the concentration of CO ranges from $0.08 \mathrm{mg} \mathrm{m}^{-3}$ to $2.42 \mathrm{mg} \mathrm{m}^{-3}$, with the maximum distribution around Hebei and Shanxi province, and the minimum distribution in the southeast, northwest, and northeast (Fig. 6a). In contrast, the concentration range of $\mathrm{NO}_{2}$ was between $2 \mu \mathrm{g} \mathrm{m} \mathrm{m}^{-3}$ and $64 \mu \mathrm{g} \mathrm{m}^{-3}$, with the maximum distribution occurring in Beijing, Tianjin, Hebei, Shandong, Henan province, and northeastern Xinjiang (Fig. 6b). However, $\mathrm{O}_{3}$ concentrations ranged from $3 \mu \mathrm{g} \mathrm{m}^{-3}$ to $198 \mu \mathrm{g} \mathrm{m}^{-3}$, with the maximum distribution in eastern China, southern China, and
Hubei province; and the minimum distribution regions including Shanxi, Sichuan and Chongqing (Fig. 6c). The concentration of $\mathrm{SO}_{2}$ ranges from $1 \mu \mathrm{g} \mathrm{m}^{-3}$ to $113 \mu \mathrm{g} \mathrm{m} \mathrm{m}^{-3}$, with the maximum distribution in northern China and in Shandong province (Fig. 6).

According to Fig. 7a, the concentration of $\mathrm{CO}$ ranges from $0.01 \mathrm{mg} \mathrm{m}^{-3}$ to $2.35 \mathrm{mg} \mathrm{m}^{-3}$ in Shanxi, Shandong, Hebei, Henan, Beijing and Tianjin had the maximum values; we also found that the minimum was chiefly located in Heilongjiang, Gansu and Tibet, and the southeast of China (the coastal urban belt). The concentration ranges of $\mathrm{NO}_{2}$ was between $0.6 \mu \mathrm{g} \mathrm{m} \mathrm{m}^{-3}$ and $60 \mu \mathrm{g} \mathrm{m}^{-3}$, with maximum values distributed primarily in northeastern China (the Beijing-Tianjin-Hebei-ShanxiHenan-Shandong region, Fig. 7b). In addition, we found that the concentration of $\mathrm{O}_{3}$ ranges from $1 \mu \mathrm{g} \mathrm{m}$ to $133 \mu \mathrm{g} \mathrm{m}^{-3}$ in Fig. 7c. The higher concentration values were observed in most areas of China, including eastern China, northern and central China (except Hunan province), and the regions of Gansu, Qinghai, Tibet (around Lhasa) and the Pearl River Delta region. The concentration of $\mathrm{NO}_{2}$ ranged from $0.3 \mu \mathrm{g} \mathrm{m}^{-3}$ and $80 \mu \mathrm{g} \mathrm{m}^{-3}$, with maximum values primarily distributed in Shanxi, Shandong and Hebei provinces (Fig. 7d).

The $\mathrm{PM}_{2.5}$ concentration ranges from $3 \mu \mathrm{g} \mathrm{m} \mathrm{m}^{-3}$ to $103 \mu \mathrm{g} \mathrm{m}^{-3}$ in 2014 (Fig. 8a), with the maximum values distributed mainly around Hebei province (Beijing-Tianjin and a part of Shandong-Henan-Hubei. The concentration of $\mathrm{PM}_{2.5}$ ranges from $1 \mu \mathrm{g} \mathrm{m} \mathrm{m}^{-3}$ to $106 \mu \mathrm{g} \mathrm{m} \mathrm{m}^{-3}$ in 2015 

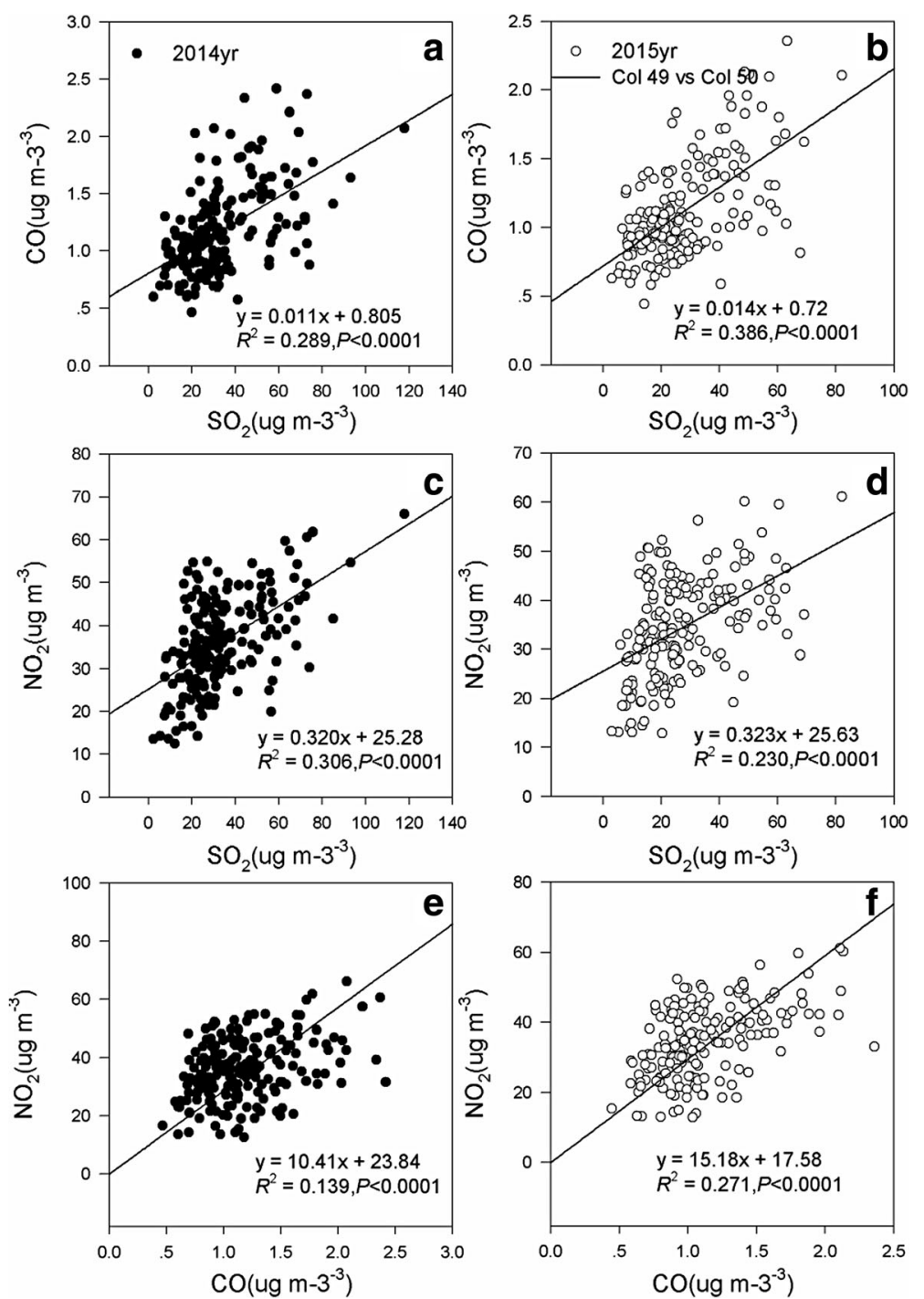

Fig. 5 The coupled analysis of the principal air pollutants in China. The graph $\mathbf{a}, \mathbf{c}$, and e represent relationships among $\mathrm{SO}_{2}, \mathrm{CO}_{1}$ and $\mathrm{NO}_{2}$ in 2014, and the graph $\mathbf{b}$, $\mathbf{d}$, and $\mathbf{f}$ represent relationships among $\mathrm{SO}_{2}, \mathrm{CO}$, and $\mathrm{NO}_{2}$ in 2015

(Fig. 8b), with maximum distribution in Hebei, Shandong, Henan and Hubei provinces, and the region of Central Bohai, while minimum values were observed in areas that include Tibet, Yunnan, Hainan, Fujian, the Pearl River Delta region and the northwest of Gansu province.

\section{Risk assessment of population exposure to air pollutants} in China from 2014 to 2015

For adult males, according to Fig. 9a, the high-risk values of $\mathrm{PM}_{10}$ main distributed in central of Xinjiang province, in Hebei province, the southwest of Shandong and eastern of Shanxi, and a part of Beijing and Tianjin. The high-risk values of $\mathrm{SO}_{2}$ occurring mainly in the central of Shandong province, the border of Hebei and Shanxi, a small part of Inner Mongolia (Erdos) and Liaoning provinces (Shenyang) (Fig. 9b). Surprisingly, the high-risk values of $\mathrm{NO}_{2}$ were mainly distributed in northeast China (Fig. 9c), regions of Hebei-Shandong-Henan-Beijing-Tianjin, a part of Inner Mongolia, the provincial capital cities of Guangzhou, Chengdu, Lanzhou, Xian, Shenyang, Changchun and Harbin, and the central of Jiangsu province. For adult females and children, a similar distribution pattern of the high-risk values for $\mathrm{PM}_{10} / \mathrm{SO}_{2} / \mathrm{NO}_{2}$ was observed. The high-risk values for $\mathrm{PM}_{10}$ distributed primarily in the central of Inner Mongolia, the south of Hebei province (Fig. 9d and g). The high-risk values for $\mathrm{SO}_{2}$ distributed in the central of Shandong province, the border of Shanxi and Hebei province, and a part of Erdos (Fig. 9e and h). As shown in Fig. 9f and i, the high-risk values of distributed primarily in Beijing-Tianjin-Hebei-Shandong regions, a part of Xinjiang province, and the cities of Chengdu, Shanghai, Wuhan, Wenzhou and Harbin. 


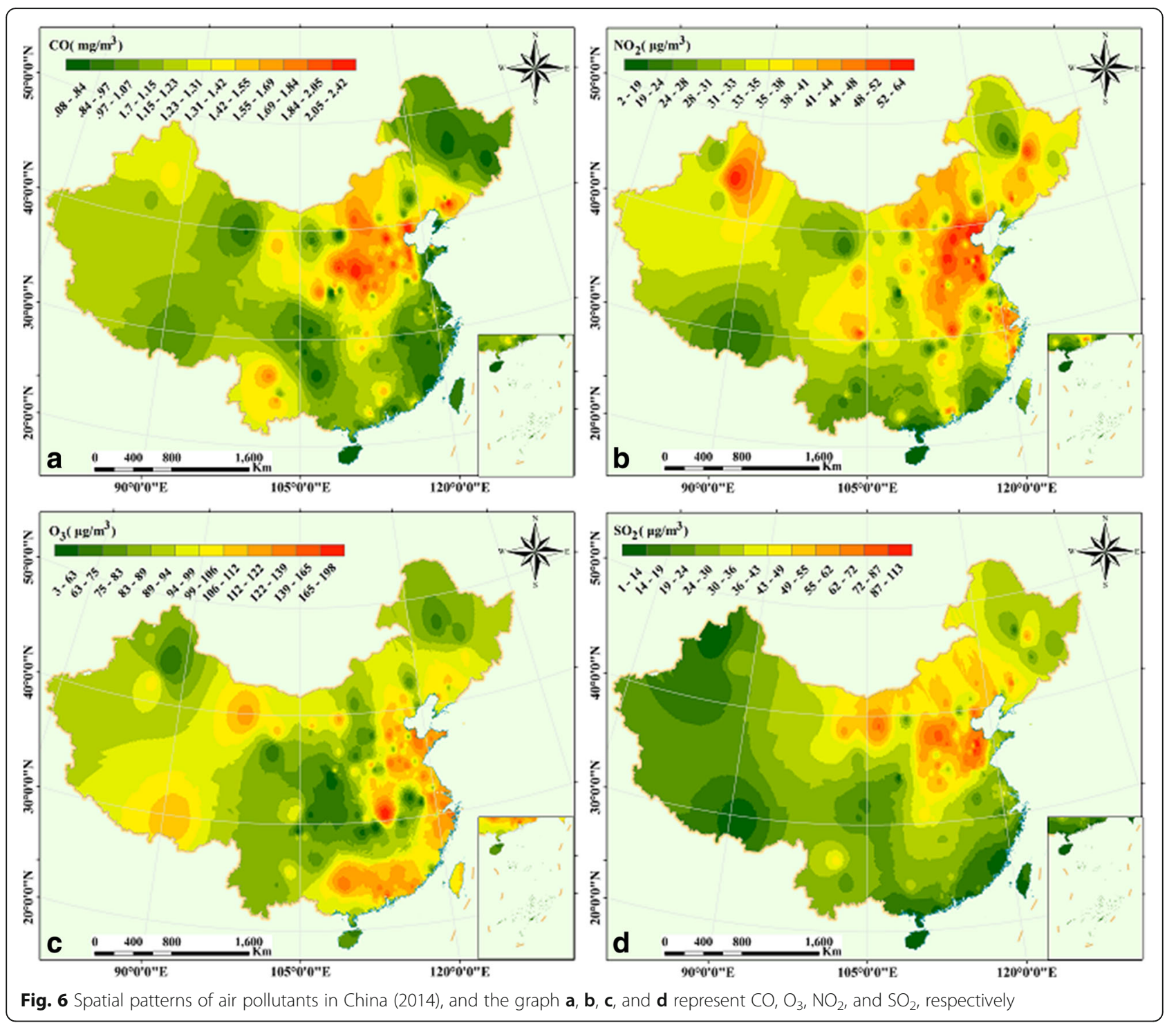

In 2015, for adult males, the high-risk values of $\mathrm{PM}_{10}$ were mainly distributed around the border of Hebei-Shandong-Henan province, thus, the cities of Baoding, Hengshui, Xingtai, Handan, Shijiazhuang in Hebei; Liaocheng, Dezhou and Heze in Shandong; and Zhengzhou in Henan (Fig. 10a). As shown in Fig. 10b, the high-risk values of $\mathrm{SO}_{2}$ occurring in the central of Shanxi (Taiyuan and Linfen) and Shandong province, and a small part of Inner Mongolia (Erdos). The highrisk values of $\mathrm{NO}_{2}$ mainly distributed in the central and northeastern of China (Fig. 10c), regions of BeijingTianjin-Hebei-Shandong-Henan, the central of Jiangsu province, and the cities of Urumchi, Lanzhou, Yanan, Chengdu, Shenyang, Changchun and Harbin, and the main city area of Chongqing. As for adult females and children, the regions of high-risk values for $\mathrm{PM}_{10} / \mathrm{SO}_{2} / \mathrm{NO}_{2}$ were alike. As for $\mathrm{PM}_{10}$, the high-risk values distribution primarily in the main city area of Baoding, Hengshui, and Handan (Fig. 10d and g). The high-risk values for $\mathrm{SO}_{2}$ occurring in the central of Shandong, the main city area of Taiyuan and Shizuishan (Fig. 10e and h). As shown in Fig. $10 \mathrm{f}$ and $\mathrm{i}$, the high-risk values of $\mathrm{NO}_{2}$ were chiefly distributed in Beijing-Tianjin-Hebei regions, the central of Shandong and the north of Henan province; and the province capital cities of Urumchi, Lanzhou, Chengdu, Wuhan and Harbin.

\section{Relationships between air pollution and human health}

The concentrations of air pollutions were the average values during 2014-2015, the mean rate of total pertussis was calculated from 30 provinces from 2004 to 2014 . General linear models analysis illustrated that the mean rate of total pertussis was significantly associated with the average concentrations of $\mathrm{PM}_{2.5}, \mathrm{PM}_{10}$ and $\mathrm{CO}$ 


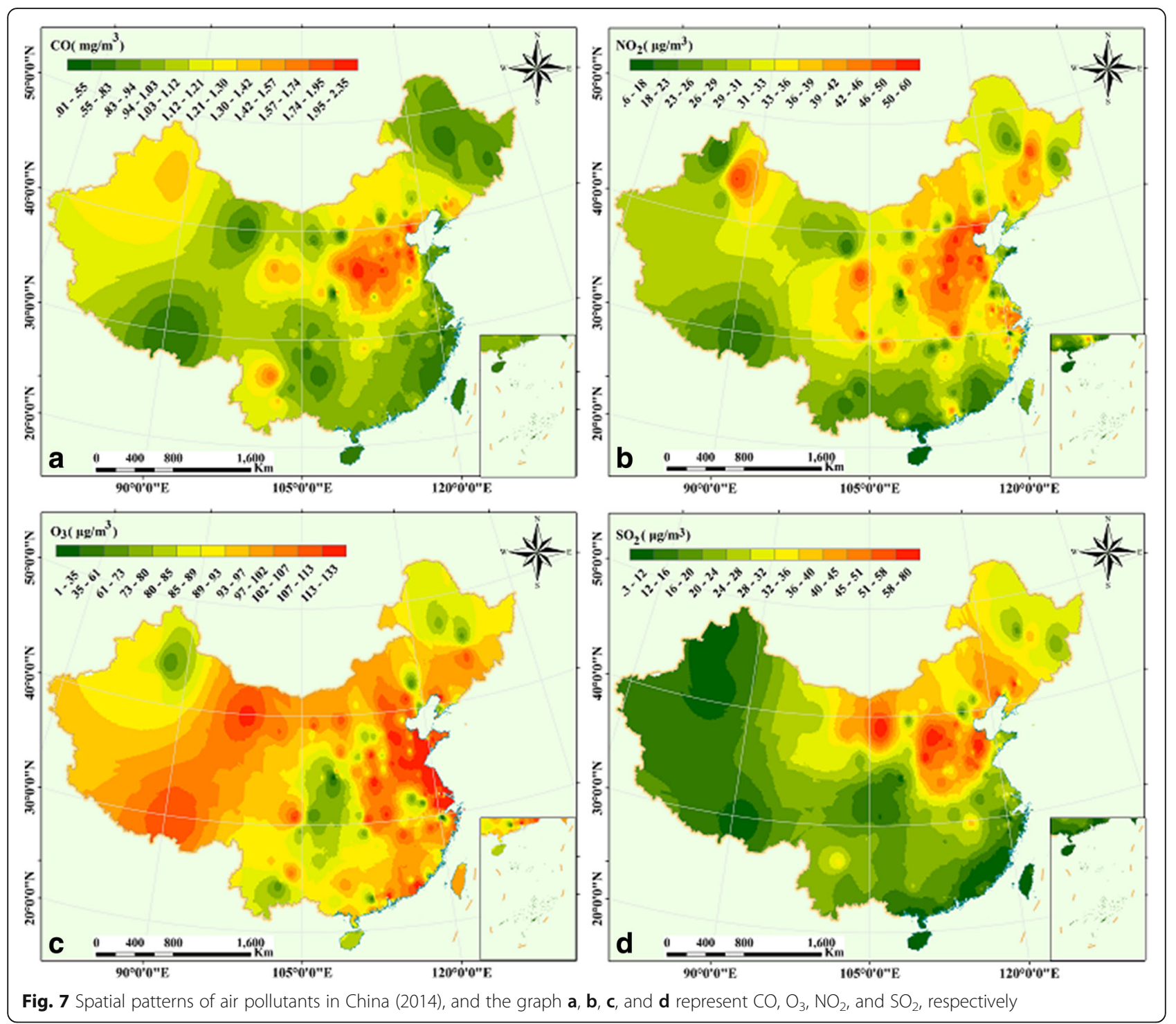

(Fig. 11a, b, and d), and the variation explained by them were $61 \%(P<0.06)$ for the rate of total pertussis. Meanwhile, the rate of total pertussis was related to $\mathrm{SO}_{2}$ and $\mathrm{NO}_{2}$ to some extent (Fig. 11c and e). However, there was no significant relationship between $\mathrm{O}_{3}$ and total pertussis (Fig. 11f).

\section{Discussion}

\section{Relationships among air pollutants}

For this study, the most extensive data for analyzing the concentration and relationship of air pollutants and time-series datasets in China were used, with the aim of understanding pollution and to mitigate the heavy haze on the Chinese mainland. The Min, Median and Max concentration of air pollutants in 2014 and 2015 were presented, after finding that the occurrence frequency narrowed and became more centralized from 2014 to
2015 (Fig. 2). Our study also identified that the main components were $\mathrm{NO}_{2}$ and $\mathrm{SO}_{2}$ in $\mathrm{PM}_{2.5}\left(R^{2}=0.395\right.$, $\left.R^{2}=0.447\right)$ in 2014 (Fig. 3) and $\left(R^{2}=0.404, R^{2}=0.533\right)$ in 2015 (Fig. 4) based on regression analysis. The same phenomenon was found in Beijing [9], central and eastern China [12, 24, 25]. Previous research has observed that the concentration of $\mathrm{SO}_{2}$ and $\mathrm{NO}_{2}$ is lowest in the autumn and highest in the winter [26]. The concentration of $\mathrm{PM}_{2.5}$ is closely correlated with $\mathrm{SO}_{2}$ and $\mathrm{NO}_{2}$ in Xi'an [23]. A joint effect of $\mathrm{NO}_{2}$ and $\mathrm{PM}$ was found [27]. Wang not only analyzed the relationships of $\mathrm{NO}_{2}, \mathrm{SO}_{2}$, and $\mathrm{PM}_{2.5}$ but also found that with the increase of sulfate and nitrate, their particle hygroscopicity enhances and drives the formation and evolution of haze pollution [12]. This means that $\mathrm{SO}_{2}$ and $\mathrm{NO}_{2}$ play an important role in the enhancement of $\mathrm{PM}_{2.5}$ [28], and reminds us to explore the relationships between $\mathrm{SO}_{2}, \mathrm{NO}_{2}$, and $\mathrm{CO}$. 

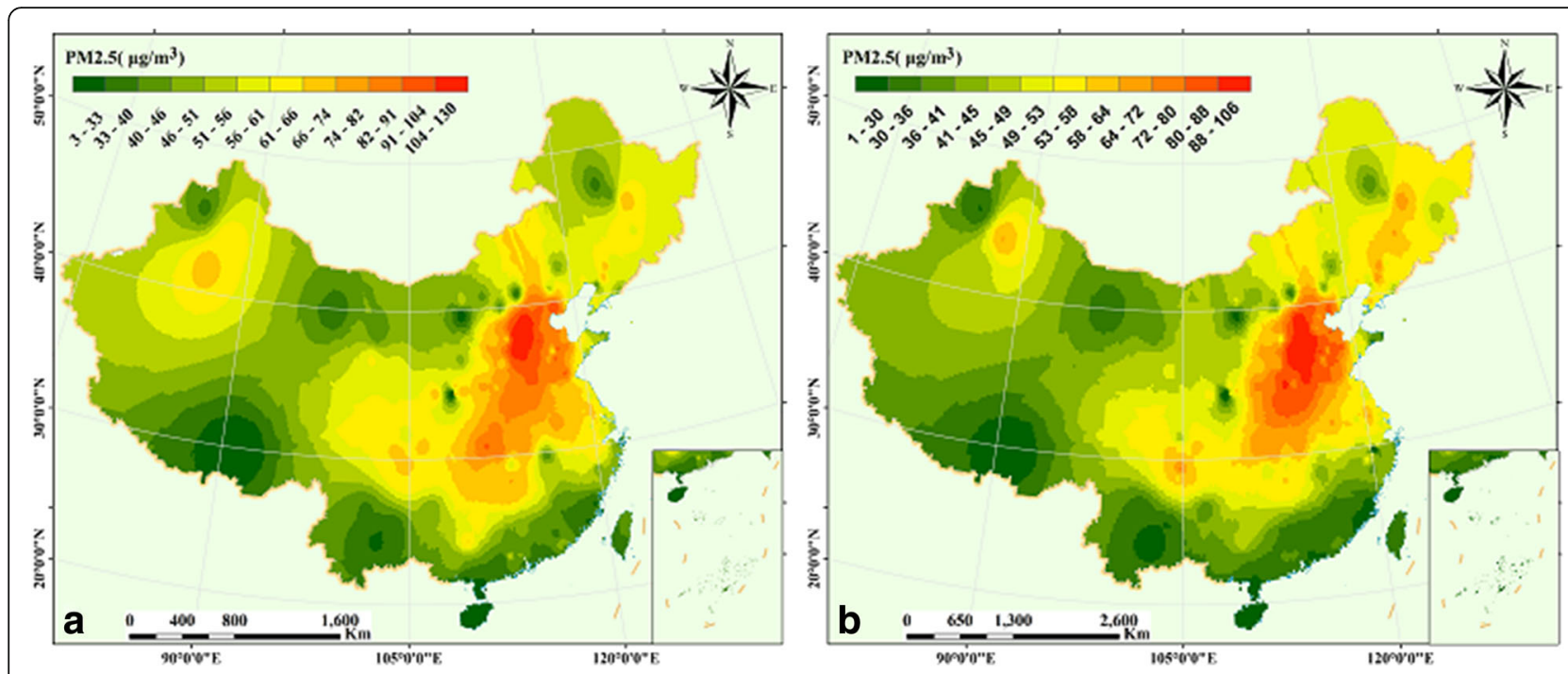

Fig. 8 Spatial patterns of air pollutant in China (graph a, b represent $\mathrm{PM}_{2.5}$ in 2014 and 2015, respectively)

As shown in Fig. 5, the most significant correlation coefficient was $\mathrm{NO}_{2}$ and $\mathrm{SO}_{2}\left(R^{2}=0.306\right)$, followed by $\mathrm{CO}$ and $\mathrm{SO}_{2}\left(R^{2}=0.289\right) ; \mathrm{NO}_{2}$ and $\mathrm{CO}\left(R^{2}=0.139\right)$ were the least pronounced in 2014. Nevertheless, a different significant association order was observed in 2015. Thus, the correlation coefficient of $\mathrm{CO}$ and $\mathrm{SO}_{2}\left(R^{2}=0.386\right)$ was greater than $\mathrm{NO}_{2}$ and $\mathrm{CO}\left(R^{2}=0.271\right)$ in 2015. This result suggests a strong relationship between $\mathrm{CO}$ and $\mathrm{SO}_{2}$, and $\mathrm{NO}_{2}$ and $\mathrm{CO}$; one study reported that the critical factor for formation droplet-mode particles was the availability of the water-vapor contents and precursor gases $\left(\mathrm{SO}_{2}\right.$ and $\left.\mathrm{NO}_{2}\right)$ [29]; in other words, under iron and manganese catalysis, the heterogeneous oxidation of $\mathrm{SO}_{2}$ and $\mathrm{NO}_{2}$ change into the secondary sulfates $\left(\mathrm{SO}_{4}{ }^{2-}\right.$ and $\mathrm{NO}_{3}{ }^{-}$) in the droplet mode [30,31], namely, the complex interaction of $\mathrm{SO}_{4}{ }^{2-}, \mathrm{NO}_{3}{ }^{-}$, congregated aerosols (e.g. sulfur dioxide, nitrogen dioxide, carbon monoxide, and so on), black carbon (the incomplete combustion of carbonaceous combustibles) determined the formation of haze and its particulate size [1, 29, 32]. $\mathrm{NH}_{3}$, however, should not be neglected, which may result in the particulate sulfate and nitrate increase [28].

\section{The spatial patterns of air pollutants}

Apart from the regression analysis of air pollutants, spatial patterns of yearly average simulation values clearly present different air pollutants concentration distributions in different regions in 2014 and 2015 (Figs. 6 and 7). A few studies found that the BeijingTianjin-Hebei-Shandong-Shanxi-Henan regions had the highest concentration of air pollutants [24, 25], including the local characteristics of high populations, city traffic, exhaust emissions, and rapid urban expansion [23, 33]. In this study, the same spatial patterns of air pollutants were observed (Figs. 6, 7 and 8). Furthermore, we found the concentration of $\mathrm{SO}_{2}, \mathrm{NO}_{2}$, and $\mathrm{CO}$ in Inner Mongolia cannot be negligible (Fig. 6a, b and d); meanwhile, the Tibet Plateau and coastal areas from Tianjin to Guangxi were affected by $\mathrm{O}_{3}$ (Fig. 6c) in 2014. In addition, similar spatial patterns of the maximum values were observed in China. However, from 2014 to 2015, the spatial variation of $\mathrm{O}_{3}$ concentration displayed a rapid increasing trend in China, especially on the Tibet Plateau (Fig. 7c), which may be influenced by its origin and long-distance transport. The $\mathrm{PM}_{2.5}$ is distributed mainly in the region of Beijing-Tianjin-ShandongHenan-Hubei in 2014 and 2015. Fortunately, its distribution narrowed and became more centralized in2015, and showed that the extent and area of $\mathrm{PM}_{2.5}$ were lower than in 2014.

Emissions of $\mathrm{PM}_{2.5}$ (97\%), $\mathrm{SO}_{2}(90 \%), \mathrm{NO}_{2}(70 \%)$ and $\mathrm{CO}(32 \%)$ were mainly due to the combustion of coal [34]. A number of previous studies have explored the origin and transportation [32, 35] of air pollutants [36, 37], including the congregated aerosols (e.g. sulfur dioxide, nitrogen dioxide, carbon monoxide, and so on), black carbon (the incomplete combustion of carbonaceous combustibles) [17], dust, sea salt [2], heavy metal, and polycyclic aromatic hydrocarbon [3], which resulted from vehicle exhaust [36], coal consumption, secondary production, stagnant meteorological conditions [13, 38-40], biomass open burning [41, 42], and petrol stations [43]. Therefore, replacing coal and fossil fuels with cleaner fuels were the fundamental methods of controlling the concentration of air pollutants [39]. Certainly, we need to encourage new technologies and energy sources for automobiles, still a major contributor to air pollution [44]. But uncertainties exist from various sources, particularly the air 


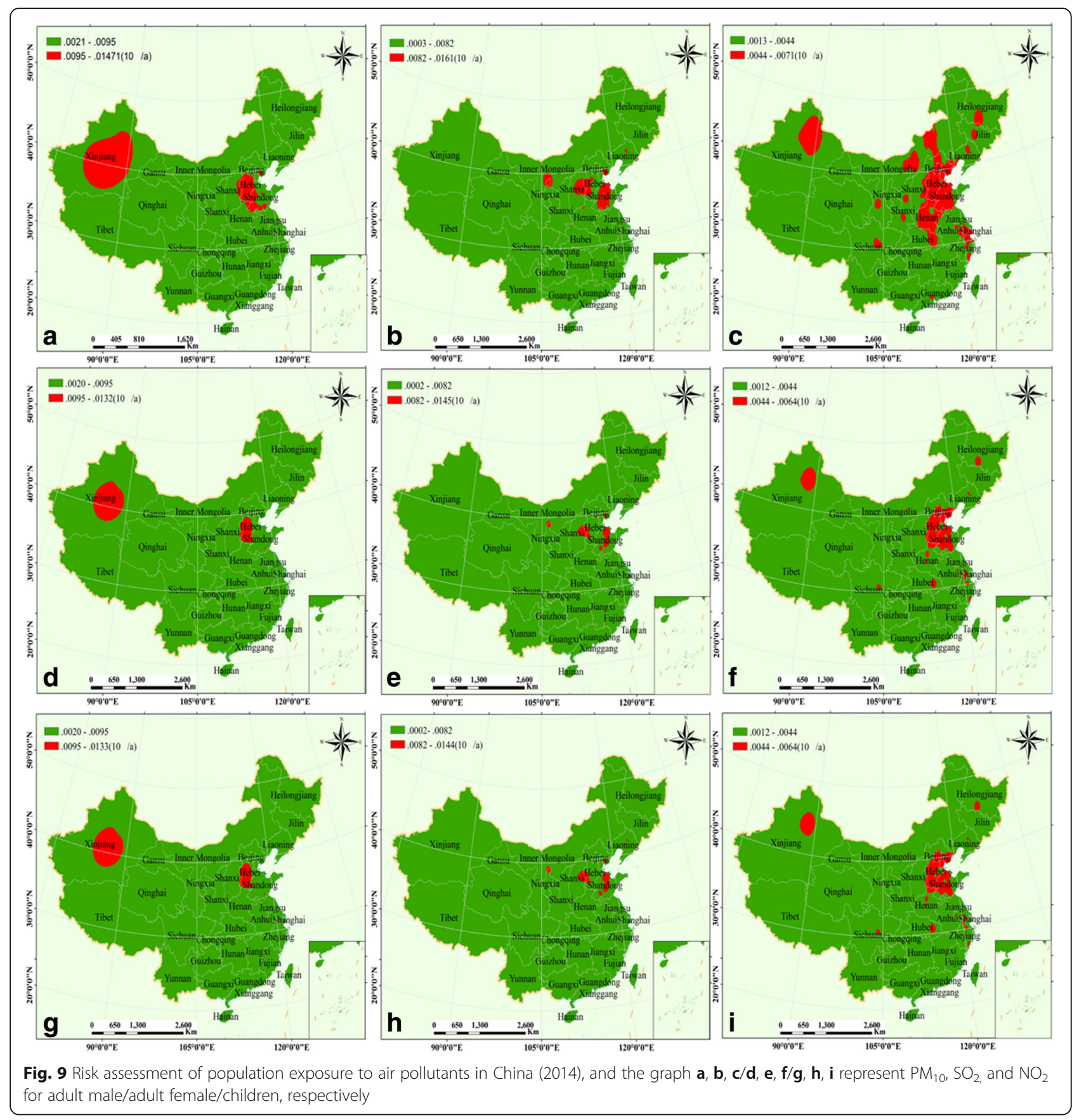

pollutants in Xinjiang Uygur Autonomous Region, which might cause sand-dust storms. Therefore, ecological conservation projects should be developed and implemented; for instance, building key forest shelterbelts to shield against sandstorms in Xinjiang.

\section{Health risk assessment and human health}

$R_{i}$ for adult males, adult females, and children, obtained for different pollutants $\left(\mathrm{PM}_{10}, \mathrm{SO}_{2}\right.$, and $\left.\mathrm{NO}_{2}\right)$ in 2014 and 2015. It was observed that the high-risk of $\mathrm{PM}_{10}$ was mainly distributed in the cities of Baoding, Hengshui, Xingtai, Handan, Shijiazhuang, Liaocheng, Dezhou, Heze and Zhengzhou (Figs. 9a, d, g and 10a, d, g), and Urumchi (Fig. 9a, d and g). The high-risk values of $\mathrm{SO}_{2}$ were chiefly distributed in the cities of Taiyuan and Linfen, a small part of Erdos, and the central of Shandong province (Figs. 9b, e, h and 10b, e, h). The high-risk values of $\mathrm{NO}_{2}$ were mainly occurring around in coastal areas from Beijing-Yangtze River Delta region-Pearl River Delta region-central, especially the cities of Urumchi, Lanzhou, 


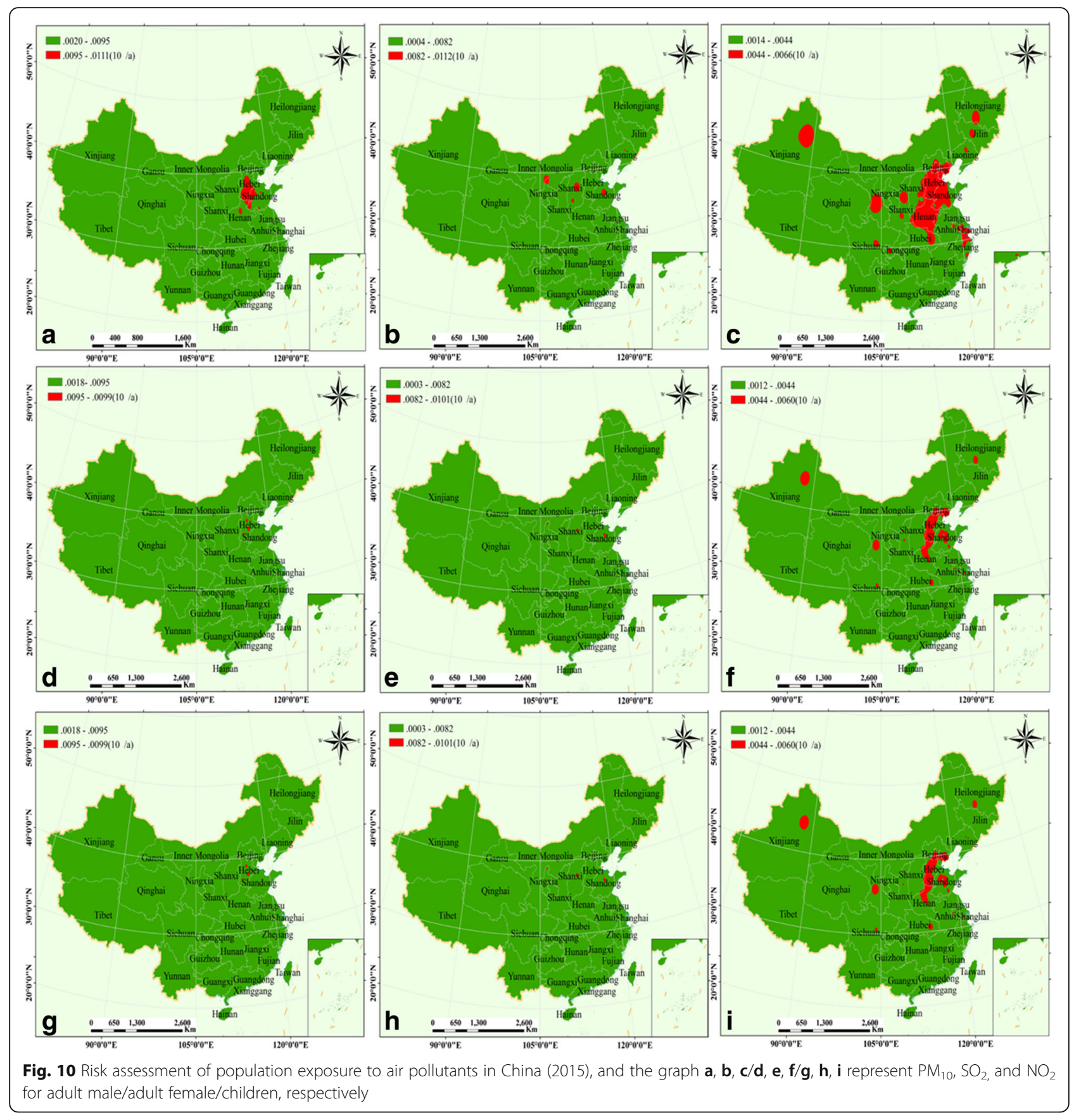

Chengdu, Wuhan and Harbin (Figs. 9c, f, i, and 10c, f, i). In comparison, the coverage area of the highest risk level was smaller in 2015 (Figs. 9 and 10).

A large portion of China's population has been significantly exposed to high-risk areas. Feng et al. [45] evaluated the ILI risk significantly associated with the concentrations of PM in Beijing during the flu season. In Guangzhou, the dust haze clearly increased mortality [19], and the $\mathrm{PM}_{2.5}$ contains toxic micro-particles that might increase the risk of respiratory disease [46].
Mortality rates increased due to the high PM pollution in Shenzhen, especially for the elderly and male populations [47]. The cardiovascular, nervous system, respiratory and blood vessels of the brain are damaged by exposure to high concentrations of $\mathrm{PM}_{2.5}$ [48]. Indeed, hemorrhagic stroke was closely associated with PM pollution [49]. Lung and cardiovascular disease are related to $\mathrm{PM}$ and $\mathrm{NO}_{2}$ [50], and $\mathrm{NO}_{2}$ was identified as the principal pollutant for respiratory diseases [18]. Local residents in Shanghai were exposed to high health risks due 

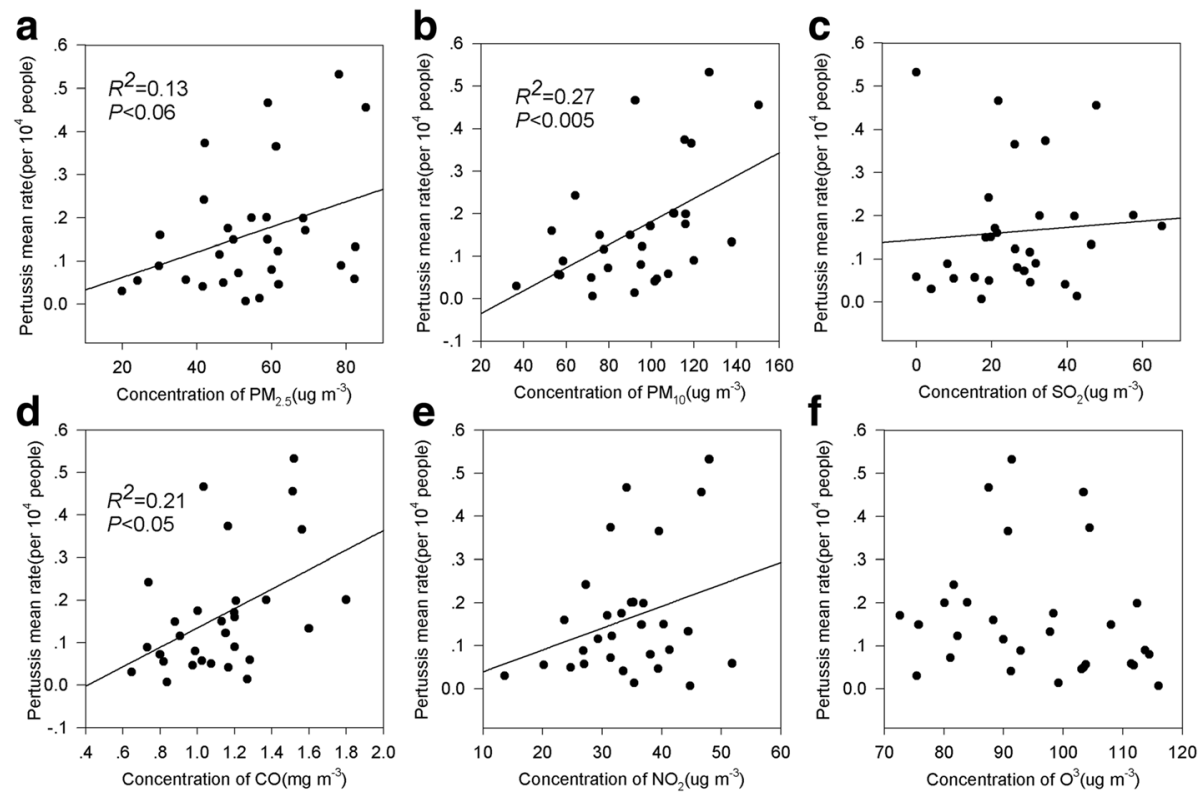

Fig. 11 The relationships of pertussis mean rate and the average concentration of air pollutions from 2014 to 2015 in 30 provinces. The graph a, $\mathbf{b}, \mathbf{c}, \mathbf{d}$, e and $\mathbf{f}$ represent the relationship between pertussis mean rate and $\mathrm{PM}_{2.5}, \mathrm{PM}_{10}, \mathrm{SO}_{2}, \mathrm{CO}, \mathrm{NO}_{2}$, and $\mathrm{O}_{3}$.

to $\mathrm{NO}_{2}$ [26]. Vulnerable people particularly (asthmatics, children, and the elderly), but all people generally, should not be exposed to high concentrations of $\mathrm{SO}_{2}$ for any length of time [51]. Meanwhile, high concentrations of $\mathrm{O}_{3}$ will irritate the eyes, nose, and throat, although long-term effects, if any, need further research [50]. One researcher has revealed that individuals exposed to biomass burningimpacted aerosols over the long term increased carcinogenic risk [6]. For these reasons and more, it is a matter of considerable urgency that policies be developed and implemented to mitigate the heavy haze in China.

\section{Limitations of the current study}

In this study, although 188 main cities across China used to get the spatial distribution patterns of air pollutions, uncertainties exist for limited data, especially in the sparsely distributed area of Xinjiang, Tibet, and Qinghai. Though significant relationships among main air pollutions were observed, inorganic substance and organic matter also correlated with each other in haze. In addition, $\mathrm{PM}_{2.5}$ has other sources of crustal materials, such as from Asian dust storms. We analyzed the relationships among gaseous pollutant emissions. Meanwhile, the average parameter values for crowds in Eq. 2 referred from articles rather than actual measurements, led to the above conclusions about health risk in China. In addition, the data of pertussis was collected from the China Statistical Yearbook on Environment, although exposure to pollutions related to the increases in morbidity, accurate and concrete data for long-term effects is urgently needed. Thus, detailed data need collect to define air pollutions and risk assessment of human health in future.

\section{Conclusions}

Air pollution is harmful to the environment and to public health. This study focused on the source apportioning and the spatial-temporal characteristics of air pollutants and analyzed the relationship between atmospheric contamination and human exposure risk in China from 2014 to 2015. The main conclusions are as follows:

(1)Regression analysis illustrates that there are close positive correlations between $\mathrm{PM}_{2.5}$ and $\mathrm{SO}_{2}, \mathrm{CO}$ and $\mathrm{NO}_{2}$, but weak correlations with $\mathrm{O}_{3}$ in 2014 and 2015. Additionally, the relationships between $\mathrm{SO}_{2}$, $\mathrm{NO}_{2}$ and $\mathrm{CO}$ were significant, suggesting that vehicle exhaust, coal consumption secondary production, stagnant meteorological conditions, and biomass open-burning are the main factors driving the formation and evolution of air pollution.

(2)In general, air pollutants in China have stabilized, showing a slight decline from 2014 to 2015. Accompanying the highest concentrations are high-risk areas distributed in provinces of Hebei, Shanxi, and Henan, and along the coast from Beijing-Yangtze River Delta to the Pearl River Delta region. The high-risk of $\mathrm{NO}_{2}$ occurred in the Beijing-Tianjin-Hebei economic belts.

Measuring air pollutants, tracking contaminant paths and assessing pollutants in different areas with volatile 
weather conditions are complex challenges and need further research. The objective of this study is to help provide healthy, sustainable development not only for the people of China but for developing and developed nations alike. In particular, this study aims to initiate a constructive forum on the Beijing-Tianjin-Hebei collaborative development.

\section{Acknowledgements}

We would like to thank Penglin Zhao for research assistance.

\section{Funding}

This research was funded by the Science and Technology Service Network Initiative (No. KFJ-SW-STS-175-01).

\section{Availability of data and materials}

The datasets generated during and/or analysed during the current study are available in the Ministry of Environmental Protection repository, http://datacenter.mep.gov.cn/.

\section{Authors' contributions}

JS contributed to the study design, JS and TCZ were involved in drafting the manuscript, approving the final draft, and agree to be accountable for the work. Both authors read and approved the final manuscript.

\section{Competing interests}

The authors declare that they have no competing interests.

\section{Consent for publication}

Not applicable.

\section{Ethics approval and consent to participate}

Not applicable.

\section{Author details}

'Institute of Geographic Sciences and Natural Resources Research, Chinese Academy of Sciences, 11A, Datun Road, Chaoyang District, Beijing 100101, China. ${ }^{2}$ Chengdu University of Technology, Chengdu 610000, China.

Received: 26 August 2016 Accepted: 13 February 2017

Published online: 20 February 2017

\section{References}

1. Zhi GR, Chen YJ, Xue ZG, Meng F, Cai J, Sheng GY, Fu JM. Comparison of elemental and black carbon measurements during normal and heavy haze periods: Implications for research. Environ Monit Assess. 2014;186:6097-106.

2. Wang YX, Zhang QQ, Jiang JK, Zhou W, Wang BY, He KB, Duan FK, Zhang Q, Philip Sajeev, Xie YY. Enhanced sulfate formation during china's severe winter haze episode in January 2013 missing from current models. J Geophys Res-Atmos. 2014;119(10):425-40.

3. Yoon YH, Horst SM, Hicks RK, Li R, de Gouw JA, Tolbert MA. The role of benzene photolysis in titan haze formation. Icarus. 2014;233:233-41.

4. Sun J, Wang J, Wei Y, Li Y, Liu M. The Haze Nightmare Following the Economic Boom in China: Dilemma and Tradeoffs. Int J Environ Res Public Health. 2016;13(4):402.

5. Huang RJ, Zhang YL, Bozzetti C, Ho KF, Cao JJ, Han YM, Daellenbach KR, Slowik JG, Platt SM, Canonaco F, Zotter P, Wolf R, Pieber SM, Bruns EA, Crippa M, Ciarelli G, Piazzalunga A, Schwikowski M, Abbaszade G, Schnelle-Kreis J, Zimmermann R, An ZS, Szidat S, Baltensperger U, El Haddad I, Prévôt AS. High secondary aerosol contribution to particulate pollution during haze events in China. Nature. 2014;514:218-22.

6. Betha R, Behera SN, Balasubramanian R. 2013 southeast asian smoke haze: Fractionation of particulate-bound elements and associated health risk. Environ Sci Technol. 2014;48:4327-35.

7. Che H, Xia X, Zhu J, Li Z, Dubovik O, Holben B, Goloub P, Chen H, Estelles V, Cuevas-Agulló E, Blarel L, Wang H, Zhao H, Zhang X, Wang Y, Sun J, Tao R, Zhang $X$, Shi G. Column aerosol optical properties and aerosol radiative forcing during a serious haze-fog month over north china plain in 2013 based on ground-based sunphotometer measurements. Atmos Chem Phys. 2014;14:2125-38.

8. Tian SL, Pan YP, Liu ZR, Wen TX, Wang YS. Size-resolved aerosol chemical analysis of extreme haze pollution events during early 2013 in urban Beijing, China. J Hazard Mater. 2014;279:452-60.

9. Liu XG, Li J, Ou Y, Han T, Hou L, Gu J, Chen C, Yang Y, Liu X, Yang T, Zhang Y, Tian H, Hu M. Formation and evolution mechanism of regional haze: A case study in the megacity Beijing, China. Atmos Chem Phys. 2013:13:4501-14.

10. Kang $\mathrm{HQ}$, Zhu B, Su JF, Wang HL, Zhang QC, Wang F. Analysis of a long-lasting haze episode in Nanjing, China. Atmos Res. 2013;120:78-87.

11. Zhao XJ, Zhao PS, Xu J, Meng W, Pu WW, Dong F, He D, Shi QF. Analysis of a winter regional haze event and its formation mechanism in the North China plain. Atmos Chem Phys. 2013;13:5685-96.

12. Wang YS, Yao L, Wang LL, Liu ZR, Ji DS, Tang GQ, ZHANG JK, SUN Y, HU B, XIN JY. Mechanism for the formation of the January 2013 heavy haze pollution episode over central and Eastern China. Sci China Earth Sci. 2014;57:14-25

13. Wang $Y J$, Li L, Chen $C H$, Huang $C$, Huang $H Y$, Feng JL, Wang $S X$, Wang $H L$, Zhang GF, Zhou M, Cheng P, Wu MH, Sheng GY, Fu JM, Hu YT, Russell AG, Wumaer A. Source apportionment of fine particulate matter during autumn haze episodes in Shanghai, China. J Geophys Res-Atmos. 2014;119:1903-14.

14. Huang LK, Yuan CS, Wang GZ, Wang K. Chemical characteristics and source apportionment of pm10 during a brown haze episode in Harbin, China. Particuology. 2011;9:32-8.

15. Zhang FW, Xu LL, Chen JS, Chen XQ, Niu ZC, Lei T, Li CM, Zhao JP. Chemical characteristics of pm2.5 during haze episodes in the urban of Fuzhou, China. Particuology. 2013;11:264-72.

16. Duan JC, Guo SJ, Tan JH, Wang SL, Chai FH. Characteristics of atmospheric carbonyls during haze days in Beijing, China. Atmos Res. 2012;114:17-27.

17. Zhang RH, Li Q, Zhang RN. Meteorological conditions for the persistent severe fog and haze event over Eastern China in January 2013. Sci China Earth Sci. 2014;57:26-35.

18. Zhang ZL, Wang J, Chen LH, Chen XY, Sun GY, Zhong NS, et al. Impact of haze and air pollution-related hazards on hospital admissions in Guangzhou, China. Environ Sci Pollut R. 2014;21:4236-44.

19. Liu T, Zhang YH, Xu YJ, Lin HL, Xu XJ, Luo Y, Xiao JP, Zeng WL, Zhang WF, Chu C, Keogh K, Rutherford S, Qian ZM, Du YD, Hu MJ, Ma WJ. The effects of dust-haze on mortality are modified by seasons and individual characteristics in Guangzhou, China. Environ Pollut. 2014;187:116-23.

20. Yadav AK, Kumar K, Kasim AMBHA, Singh MP, Parida SK, Sharan M. Visibility and incidence of respiratory diseases during the 1998 haze episode in Brunei Darussalam. Pure Appl Geophys. 2003;160:265-77.

21. U.S. Environmental Protection Agency (EPA). Epa releases probabilistic risk assessment guidance for superfund. Hazardous Waste Cons. 2002;20:B17B21.

22. Dong J, Zhang P, L N, Tian ZH. Health risk assessment of main air pollutants in yulin city. Ground water. 2014;36:209-210

23. Li YA, Miao QG, Song JF, Quan YN, Li WS. Single image haze removal based on haze physical characteristics and adaptive sky region detection. Neurocomputing. 2016;182:221-34.

24. Wang H, Tan SC, Wang Y, Jiang C, Shi GY, Zhang MX, Che HZ. A multisource observation study of the severe prolonged regional haze episode over Eastern China in January 2013. Atmos Environ. 2014;89:807-15.

25. Wang XF, Chen JM, Sun JF, Li WJ, Yang LX, Wen L, Yang LX, Wen LA, Wang WX, Wang XM, Collett Jr JL, Shi Y, Zhang QZ, Hu JT, Yao L, Zhu YH, Sui X, Sun XM, Mellouki A. Severe haze episodes and seriously polluted fog water in Ji'nan, China. Sci Total Environ. 2014;493:133-7.

26. Zhao WC, Cheng JP, Li DL, Duan YS, Wei HP, Ji RX, Wang WH. Urban ambient air quality investigation and health risk assessment during haze and non-haze periods in Shanghai, China. Atmos Pollut Res. 2013:4:275-81.

27. Kirrane E, Svendsgaard D, Ross M, Buckley B, Davis A, Johns D, et al. A comparison of risk estimates for the effect of short-term exposure to $\mathrm{pm}, \mathrm{nO}_{2}$ and $\mathrm{co}$ on cardiovascular hospitalizations and emergency department visits: Effect size modeling of study findings. AtmosphereBasel. 2011:2:688-701.

28. Ye XN, Ma Z, Zhang JC, Du HH, Chen JM, Chen H, et al. Important role of ammonia on haze formation in shanghai. Environ Res Lett. 2011;6:024019.

29. Kang E, Han J, Lee M, Lee G, Kim JC. Chemical characteristics of size-resolved aerosols from asian dust and haze episode in Seoul Metropolitan City. Atmos Res. 2013;127:34-46. 
30. Frossard AA, Shaw PM, Russell LM, Kroll JH, Canagaratna MR, Worsnop DR, Quinn PK, Bates TS. Springtime arctic haze contributions of submicron organic particles from european and asian combustion sources. J Geophys Res-Atmos. 2011:116:D05205.

31. Wang XF, Wang WX, Yang LX, Gao XM, Nie W, Yu YC, Xu PJ, Zhou Y, Wang $Z$. The secondary formation of inorganic aerosols in the droplet mode through heterogeneous aqueous reactions under haze conditions. Atmos Environ. 2012;63:68-76.

32. Zhang XL, Huang YB, Zhu WY, Rao RZ. Aerosol characteristics during summer haze episodes from different source regions over the coast city of North China plain. J Quant Spectrosc Ra. 2013;122:180-93.

33. Lin G, Fu JY, Jiang D, Hu WS, Dong DL, Huang YH, Zhao MD. Spatio-temporal variation of pm2.5 concentrations and their relationship with geographic and socioeconomic factors in China. Int J Env Res Pub He. 2014;11:173-86.

34. Xie YY, Zhao B, Zhang L, Luo R. Spatiotemporal variations of pm2.5 and pm10 concentrations between 31 chinese cities and their relationships with so2, no2, co and o-3. Particuology. 2015;20:141-9.

35. Jung J, Kim YJ. Tracking sources of severe haze episodes and their physicochemical and hygroscopic properties under asian continental outflow: Long-range transport pollution, postharvest biomass burning, and asian dust. J Geophys Res-Atmos. 2011;116:D02206.

36. Liu JW, Li J, Zhang YL, Liu D, Ding P, Shen CD, Shen K, He QF, Ding X, Wang XM, Chen DH, Szidat S, Zhang G. Source apportionment using radiocarbon and organic tracers for pm2.5 carbonaceous aerosols in guangzhou, south china: Contrasting local- and regional-scale haze events. Environ Sci Technol. 2014:48:12002-11.

37. Tang LL, Yu HX, Ding AJ, Zhang YJ, Qin W, Wang Z, Chen WT, Hua Y, Yang XX. Regional contribution to PM1 pollution during winter haze in Yangtze River Delta, China. Sci Total Environ. 2016;541:161-6.

38. Sun $Y L$, Jiang $Q$, Wang ZF, Fu PQ, Li J, Yang $T$, Yin $Y$. Investigation of the sources and evolution processes of severe haze pollution in Beijing in January 2013. J Geophys Res-Atmos. 2014;119:4380-98.

39. Wang K, Liu YN. Can beijing fight with haze? Lessons can be learned from London and Los angeles. Nat Hazards. 2014;72:1265-74.

40. Wang LT, Wei Z, Yang J, Zhang Y, Zhang FF, Su J, Meng CC, Zhang Q. The 2013 severe haze over southern hebei, china: Model evaluation, source apportionment, and policy implications. Atmos Chem Phys. 2014;14:3151-73.

41. Cheng Z, Wang S, Fu X, Watson JG, Jiang J, Fu Q, Chen C, Xu B, Yu J, Chow JC, Hao J. Impact of biomass burning on haze pollution in the yangtze river delta, China: A case study in summer 2011. Atmos Chem Phys. 2014; 14:4573-85.

42. Phoothiwut $\mathrm{S}$, Junyapoon S. Size distribution of atmospheric particulates and particulate-bound polycyclic aromatic hydrocarbons and characteristics of pahs during haze period in Lampang province, Northern Thailand. Air Qual Atmos HIth. 2013;6:397-405.

43. Demirel G, Ozden O, Dogeroglu T, Gaga EO. Personal exposure of primary school children to btex, no2 and ozone in Eskisehir, Turkey: Relationship with indoor/outdoor concentrations and risk assessment. Sci Total Environ. 2014;473:537-48.

44. Fang YP. Economic welfare impacts from renewable energy consumption: The China experience. Renew Sust Energ Rev. 2011;15:5120-8.

45. Feng C, Li J, Sun W, Zhang Y, Wang Q. Impact of ambient fine particulate matter (PM2.5) exposure on the risk of influenza-like-illness: a time-series analysis in Beijing, China. Environ Health. 2016;15:17.

46. Pan QC, Yu YS, Tang ZH, Xi M, Zang GQ. Haze, a hotbed of respiratoryassociated infectious diseases, and a new challenge for disease control and prevention in China. Am J Infect Control. 2014;42:688-688.

47. Zhang FY, Liu XJ, Zhou L, Yu Y, Wang L, Lu JM, Wang WY. Spatiotemporal patterns of particulate matter (pm) and associations between pm and mortality in Shenzhen, China. BMC Public Health. 2016;16.

48. Li MN, Zhang LL. Haze in China: Current and future challenges. Environ Pollut. 2014;189:85-6.

49. Lin HL, Tao J, Du YD, Liu T, Qian ZM, Tian LW, et al. Differentiating the effects of characteristics of pm pollution on mortality from ischemic and hemorrhagic strokes. Int J Hyg Envir Heal. 2016;219:204-11.

50. Liu SK, Cai S, Chen Y, Xiao B, Chen P, Xiang XD. The effect of pollutional haze on pulmonary function. J Thorac Dis. 2016;8:E41-56.

51. Klose CD. Health risk analysis of volcanic so 2 hazard on vulcano island (Italy). Nat Hazards. 2007;43:303-17.

\section{Submit your next manuscript to BioMed Central and we will help you at every step:}

- We accept pre-submission inquiries

- Our selector tool helps you to find the most relevant journal

- We provide round the clock customer support

- Convenient online submission

- Thorough peer review

- Inclusion in PubMed and all major indexing services

- Maximum visibility for your research

Submit your manuscript at www.biomedcentral.com/submit 